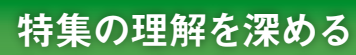 Multiple Choice Questions
}

1 Parkinson病治療薬について正しいのはどれか。1つ選べ。

（a）選択的アデノシン受容体刺激薬がParkinson病治療に用いられている.

（b）非麦角系ドパミンアゴニストの特異な副作用として心蔵弁膜症がある.

（c）ゾニサミドはジスキネジアを有するParkinson病患者には使用できない.

（d）Parkinson病に対するゾニサミドの1日使用量はてんかんに対する使用量よりも少ない.

(e) COMT阻害薬はレボドパからドパミンへの代謝を阻害する.

2 大脳基底核回路の間接経路と関係性の低いものはどれか。2つ選べ。
(a) アデノシンA1 受容体
(b) アデノシンA2A受容体
(c) ドパミンD1受容体
(d) ドパミンD2 受容体
(e) $\delta 1$ 受容体

3 Parkinson病の認知症について正しいものはどれか. 2つ選べ.
（a）合併は稀である.
（b）進行期になると注意, 記憶, 遂行機能障害が出現し, 認知症に至る.
（c）幻覚・妄想を伴う場合, Lewy小体型認知症と診断される.
(d) しばしばAlzheimer病と同様のアミロイド $\beta$ 蛋白が沈着する.
（e）コリンエステラーゼ阻害薬が有効な例がある.

4 Parkinson病の幻覚・妄想について正しいものはどれか。1つ選べ。

（a）多くは抗Parkinson病薬の副作用で生じる.

（b）幻覚では幻聴，妄想では被害妄想が特徴的である.

（c）運動障害，うつとともに患者，介護者のQOLを障害する主要因となる.

（d）治療にはまず非定型抗精神病薬を試みる.

(e) コリンエステラーゼ阻害薬の効果は期待できない. 
5 救急入院の原因で，Parkinson病患者が一般高齢者よりも頻度が高いものはどれか．2つ選 ベ.
（a）骨折・外傷
（b）悪性腫瘍
(c) 心筋梗塞
(d) 脳卒中
(e) 肺炎

6 悪性症候群・Parkinsonism-hyperpyrexia syndromeの特徵でないのはどれか。1つ選べ。
(a) 発熱
(b) 筋強剛
（c）ジスキネジア
(d) 高creatine kinase血症
(e) 発汗

7 次のうち正しいのはどれか。2つ選べ。

（a）脳血管障害性パーキンソニズムは1-dopa製剤への反応性が良好である.

（b）パーキンソニズムを呈し，頭部CT，頭部MRI検査で虚血性変化が証明されれば脳血管障害 性パーキンニズムと診断できる.

（c）Parkinson病と脳血管障害性パーキンソニズムを合併する症例は少なくない.

（d）DAT SPECT検査のみでParkinson病と脳血管障害性パーキンソニズムは鑑別できる.

（e）脳血管障害性パーキンソニズムは下肢の症状が主体である.

8 次のうち正しいものはどれか.1つ選べ。

（a）細胞移植療法によってParkinson病の非運動症状も軽快する.

（b）1-dopa腸管内持続投与（DUODOPA ${ }^{\circledR} ）$ によって血中ドパミン濃度が安定する.

(c) Continuous dopaminergic stimulation（CDS）によって運動合併症が増加する.

（d）iPS細胞は多能性，自己増殖能を備えた肧細胞由来の細胞である.

（e）遺伝子治療は経静脈的に投与するため，安全性は高い. 


\section{MCQ \解答と解説}

\section{特集の理解を深める Multiple Choice Questions}

解答と解説

問題 1

解答 : (d)

\section{解 説}

非ドパミン系Parkinson病治療薬として選択 的アデノシンA2A受容体拮抗薬が用いられてい る。ゾニサミドは抗てんかん薬として用いられ る量と比べてはるかに少ない1日量（25〜 $50 \mathrm{mg}$ ）でParkinson病患者に使用されている. また, ウェアリングオフへの対処として, ジス キネジアの有無にかかわらずドパミン系治療薬 に追加して使用できる. COMT阻害薬はレボド パから 3-OMDへの代謝を阻害することにより， レボドパの有効時間を延長させる，心臓弁膜症 は麦角系ドパミンアゴニストにみられる副作用 である.

\section{問題 2}

解答 : (a)，(c)

\section{解 説}

アデノシンA1受容体, ドパミンD1受容体は 直接経路に発現している受容体である。ドパミ ンと一部のドパミンアゴニストはドパミンD1 受容体に作用する.アデノシンA2A受容体, ド パミンD2受容体, $\delta 1$ 受容体は間接経路に発現し ている.イストラデフィリンはアデノシンA2A 受容体拮抗薬であり,ゾニサミドは $\delta 1$ 受容体ア ゴニスト作用を有する。ドパミンと全てのドパ ミンアゴニストはドパミンD2受容体に作用す る.
問題 3

解答 : (d)，(e)

\section{解 説}

James Parkinsonは認知症と感覚障害は生じ ないと記載したが, Parkinson病では初期から認 知機能低下が高頻度にみられ, 進行期には過半 数が認知症となる. Lewy小体型認知症はParkinson病と連続する病理を呈するが, 認知症や幻 覚・妄想がパーキンソニズムより先に, あるい は発現 1 年以内に生じた場合に診断する.

認知症を伴うParkinson病では大脳皮質にび まん性にLewy小体がみられるが, Alzheimer病 の病理であるアミロイド $\beta$ 蛋白が蓄積する例が 稀ならずあることが報告されている，治療には 抗認知症薬の有効性が報告されている.

\section{問題 4}

\section{解答 : (c)}

\section{解 説}

Parkinson病経過中, しばしば幻覚・妄想が出 現する。認知症がある場合に出現頻度が高い。 しばしば薬剤の開始，増量時に出現するが，主 因は中枢コリン系の変性脱落やレビー病理の広 がりなど, 認知機能障害の背景と共通するParkinson病病態の進行によると考えられる.幻覚, 妄想の性状であるが, 幻覚では生々しい幻視が 特徵的である。妄想は物盗られ, 被害, 被毒, 珔妬, 誤認妄想など様々である。誤認妄想は他 の妄想と比べ, 特に高頻度ではないが, Parkinson病, Lewy小体型認知症に特徵的にみられる. 認知機能低下や幻覚・妄想は家族の介護負担を 高め, 介護意欲を削ぎ，介護負施設入所を考え 
る要因となる，治療にはまず抗Parkinson病薬の 調整を行う。幻覚を生じやすい抗コリン薬, ア マンタジンから中止する，減薬すると運動障害 が悪化するため, 軽症例では抗認知症薬の併用 を第一選択とする場合もある。幻視のみの以上 であれば，コリンエステラーゼ阻害薬のみで改 善が期待できる. 抗精神病薬はこれら手段が奏 効しない場合や，妄想による拒絶のため治療的 接近が困難となり, 緊急の改善が必要な場合に 選択する。

\section{問題 5}

解答：(a)，(e)

\section{解 説}

Parkinson病患者の救急受診や入院の原因に 関して, 頻度的には転倒・骨折, 肺炎, 心疾患・ 失神, 泌尿器疾患 (主に尿路感染症), 運動症状 の急性増悪, 精神症状が多い。一般高齢者と比 べた 2014 年Bragaらの報告では, 脳卒中, 心筋 梗塞, 腫瘍はPD患者で少なく, 肺炎, 尿路感染 症，骨折を含む外傷はPD患者で多い傾向がみら れた。

\section{問題 6}

解答 : (c)

\section{解 説}

Parkinsonism-hyperpyrexia syndromeは悪 性 症候群と同じ症候を呈し, $38^{\circ} \mathrm{C}$ 以上の発熱，筋 強剛の増悪, 発熱, 発汗, 頻脈, 血圧変動等の 自律神経症状, 意識の変容, 高CK血症が特徴で ある、鑑別は激しいジスキネジアを呈するdyskinesia-hyperpyrexia syndromeとモノアミン酸 化酵素阻害薬とセロトニン再吸収阻害薬の併用 によりみられるセロトニン症候群であり, セロ トニン症候群は発熱, 筋強剛のほか, ミオクロー ヌスや腱反射の克進が特徴である.

\section{問題 7}

解答：(c)，(e)

\section{解 説}

脳血管障害性パーキンソニズムは1-dopa製剤 への反応が不良であり，下肢の症状が主体であ る. パーキンソニズムと画像上の虚血性変化の みで短絡的に診断してはならない。

また，DAT SPECT検査はパーキンソニズムを 来たす疾患の鑑別に有用ではあるが，あくまで 他の画像検查と併用し，診断の補助として使用 するべきであり，それのみでの鑑別はできな い. Parkinson病, 脳血管障害性パーキンソニズ ムともに加齢とともに有病率が上昇するため, 両者を合併することは少なくない.

\section{問題 8}

\section{解答 : (b)}

\section{解 説}

continuous dopaminergic stimulation (CDS) は ドパミン血中濃度を一定にすることで，より生 理的状態に近づけるという治療概念で，これに より運動合併症が減少することが認められてい る.ドパミンアゴニスト徐放薬や1-dopa腸管内 持続投与がある。細胞移植療法や遺伝子治療で はいずれも運動症状には有効であるが非運動症 状には効果がない。また，いずれも外科的に脳 内へ直接投与するため，侵襲を伴う。iPS細胞は 胚細胞を使わず線維芽細胞を改変することで作 られるため，倫理的問題が発生しない. 


\section{問題作成者}

永井 将弘（愛媛大学医学部附属病院

臨床研究支援センター)

柏原健一（岡山旭東病院神経内科）

坪井 義夫（福岡大学医学部神経内科学教室）

金子厚 (北里大学医学部神経内科学)

馬場 孝輔 (大阪大学医学部神経内科学)

著者のCOI (conflicts of interest) 開示: 各作成者の論文 ページに記載 